UDC 577.346

doi: https://doi.org/10.15407/ubj91.02.052

\title{
BLOOD COAGULATION PARAMETERS IN RATS WITH ACUTE RADIATION SYNDROME RECEIVING ACTIVATED CARBON AS A PREVENTIVE REMEDY
}

\author{
V. CHERNYSHENKO ${ }^{1 凶}$, E. SNEZHKOVA ${ }^{2}$, M. MAZUR $^{2}$, T. CHERNYSHENKO ${ }^{1}$, \\ T. PLATONOVA 1 , O. SYDORENKO' ${ }^{2}$ E. LUGOVSKOY ${ }^{1}$, V. NIKOLAEV ${ }^{2}$ \\ ${ }^{1}$ Palladin Institute of Biochemistry, National Academy of Sciences of Ukraine, Kyiv; \\ 凶e-mail: bio.cherv@gmail.com; \\ ${ }^{2}$ RE Kavetsky Institute of Experimental Pathology, Oncology \\ and Radiobiology, National Academy of Sciences of Ukraine, Kyiv
}

Received: 13 December 2018; Accepted: 20 March 2019

Radiation-induced coagulopathy (RIC) is one of the major causes of death during acute radiation syndrome (ARS). The aim of this study was to characterize the responses of the hemostasis system to ARS of a moderate level on the $1^{\text {st }}$ and $9^{\text {th }}$ days after irradiation. We aimed to identify molecular markers of the blood coagulation system that are most affected by ARS and to estimate the enterosorption effect on the development of irradiation-induced changes. Platelet aggregation rate, activated partial thromboplastin time (APTT) and fibrinogen concentration were determined by standard methods. Level of protein $C(P C)$ was measured using chromogenic substrate S2366 (p-Glu-Pro-Arg-pNa) and Agkistrodon halys halys snake venom activating enzyme. Functionally inactive forms of prothrombin (FIFPs) were determined using two activators in parallel - thromboplastin or prothrombin activator from Echis multisqumatis venom. Rats of both irradiated groups had a higher risk of intravascular clotting in comparison to both control groups. Statistically significant shortening of clotting time in the APTT test (24 4 s vs. $33 \pm 5 s)$ and increased fibrinogen concentration $(4.2 \pm 0.6 \mathrm{mg} / \mathrm{ml} v \mathrm{vs} .3 .2 \pm 0.3 \mathrm{mg} / \mathrm{ml})$ were detected. Both parameters were normalized on the $9^{\text {th }}$ day after irradiation. However the platelet count was decreased $\left(0.3 \cdot 10^{6} \pm 0.05 \cdot 10^{6} 1 / \mu \mathrm{l} v \mathrm{~s} .0 .145 \cdot 10^{6} \pm 0.04 \cdot 10^{6} \mathrm{l} / \mu \mathrm{l}\right)$ due to the impaired megakaryocytic function. The level of PC was decreased after X-ray irradiation (70 $\pm 10 \%)$ and partly restored on the $9^{\text {th }}$ day after irradiation (87 $\left.\pm 10 \%\right)$. Administration of activated carbon (AC) inhibited the drop in the PC concentration after X-ray irradiation (86 $\pm 15 \%$ ) and accelerated its restoration on the 9th day $(103 \pm 14 \%)$. The statistically significant accumulation of FIFPs was detected in blood plasma of irradiated rats at the $1^{\text {st }}$ and $9^{\text {th }}$ days after irradiation. No FIFPs were found in any irradiated rat treated with AC. Characterization of the hemostasis system of rats that were exposed to a semilethal dose of $X$-rays allowed us to select parameters that can be used for monitoring of ARS development. Apart of from basic coagulation tests (APTT) and the measurement of platelet aggregation, fibrinogen and protein $C$ level we can recommend the determination of FIFPs as a useful tool for estimation of the hemostasis response after irradiation with $X$-rays. This test indicates the intravascular thrombin generation and can help predict thrombotic complication or disseminated intravascular coagulation. Determination of FIFPs in blood plasma of irradiated rats allowed us to study the enterosorption effect on the development of irradiation-induced changes. It was shown that enterosorption with AC prevented accumulation of FIFPs which appears to be a newly discovered antithrombotic effect of therapy with AC. ARS influenced hemostasis by inducing thrombin generation (indicated by FIFPs generation), low-grade inflammation (indicated by PC concentration decrease) and thrombocytopenia. Enterosorption with AC minimizes inflammation and pro-coagulant processes caused by a moderate dose of X-ray irradiation. Accumulation of FIFPs can be assumed to be one of the most sensitive markers of the blood coagulation response to $X$-ray irradiation.

Ke yw ords: enterosorption, activated carbon, platelets, blood coagulation, acute radiation syndrome of moderate level.

(C) 2019 Chernyshenko V. et al. This is an open-access article distributed under the terms of the Creative Commons Attribution License, which permits unrestricted use, distribution, and reproduction in any medium, provided the original author and source are credited. 
A cute radiation syndrome (ARS) is a complex due to pathological outcomes after irradiation by 0.5 Gy and above [1]. The reason for death from ARS is believed to be radiation-induced multi-organ dysfunction including damage of endothelial cells and consequential systemic inflammation [2]. It is not surprising then that blood coagulation disorder is the main factor for death resulting from ARS in mammals, including humans [3]. These disorders are called radiation-induced coagulopathy (RIC) and consist mainly of microvascular thrombosis and consequent coagulopathy caused by a fatal drop in coagulation factors $[4,5]$. This phenomenon of clotting and bleeding at the same time is known as disseminated intravascular coagulation (DIC) [6]. On the other hand, the blood coagulation system can be assumed to be one of the most sensitive systems to inflammatory processes in humans [7]. Inflammation directly leads to activation of coagulation, and coagulation also considerably affects inflammatory activity [8]. As far as inflammation being the crucial point of most of ARS-induced pathogenetic changes [9], blood coagulation parameters can indicate not only the inflammatory processes, but also the rate of radiation syndrome development. Due to our knowledge, blood coagulation substantially reacts to liver injury [10] and low-grade inflammation during diabetes [11].

Study of blood coagulation parameters can indicate not only the inflammatory processes, but can also serve as biomarkers of ARS and reflect the efficacy of preventive treatment Activated carbon (AC) acts by removing exogenous and endogenous toxins and is a promising remedy for ARS [12]. It is known that AC possesses prominent anti-inflammatory action [13]. Based on these findings, we expected that the anti-inflammatory action of enterosorption would suppress the activation of blood coagulation.

The aim of this study was to characterize the responses of the hemostasis system to ARS of a moderate level on the $1^{\text {st }}$ and $9^{\text {th }}$ days after the irradiation. The effect of oral administration of mesoporous AC with a highly developed surface
$\left(\mathrm{S}_{\mathrm{BET}}=2900 \mathrm{~m}^{2} / \mathrm{g}\right)$ on coagulation parameters of rats exposed to a semilethal dose of X-rays was studied. We aimed to identify molecular markers of the blood coagulation system that are most affected by ARS and to estimate the enterosorption effect on the development of irradiation-induced changes.

\section{Materials and Methods}

Blood sampling. Samples of rat blood were collected by heart puncture. 3.8\% sodium citrate was added to blood immediately after collection. Plateletrich plasma (PRP) was prepared from citrated blood by centrifugation at $1000 \mathrm{rpm}$ for $30 \mathrm{~min}$. Platelet poor plasma (PPP) was obtained from PRP by centrifugation of PRP for $15 \mathrm{~min}$ at $1500 \mathrm{rpm}$.

Reagents. Chromogenic substrates S2238 (H-DPhe-Pip-Arg-pNA), S2765 (Z-D-Arg-Gly-Arg-pNA) and S2236 (p-Glu-Pro-Arg-pNa) were purchased from BIOPHEN (Neuville-sur-Oise, France). APTTreagent, thromboplastin and protein C (PC) activator were purchased from Renam (Moscow, Russia). Ecamulin was purified from Echis multisquamatis venom according to the method of Solov'yev et al [14]. Factor X activator from Daboia russellii venom (RVV) and adenosine diphosphate (ADP) were purchased from Sigma-Aldrich (St. Louis, USA).

Activated carbon. AC was prepared by RE Kavetsky Institute of Experimental Pathology, Oncology and Radiobiology, NAS of Ukraine, Kyiv, Ukraine and had the following properties: enterosorbent (ES) - granulated with diameter $<0.25 \mathrm{~mm}$, and highly activated with bulk density of $0.12 \mathrm{~g} /$ $\mathrm{cm}^{3}$, BET surface of $2918 \mathrm{~m}^{2} / \mathrm{g}$ and BJH volume of $4.5 \mathrm{~cm}^{3} / \mathrm{g}$ (measured by nitrogen porosimetry).

Animal model. Male white Wistar rats (200 \pm 20 g, $n=40$ ) from the Institute of Experimental Pathology, Oncology and Radiobiology vivarium were divided into 4 groups of 10 animals each 2 weeks before the experiment for adaptation: $1^{\text {st }}$ group - rats as irradiated control exposed to external X-ray irradiation at a dose of 6 Gy (self- recuperation group without ES) $2^{\text {nd }}$ group - rats with 6 Gy irradiation exposure + AC per oral administration

\footnotetext{
Abbreviations: RIC - Radiation-induced coagulopathy; AC - activated carbon; ARS - acute radiation syndrome; ES enterosorbent; APTT - activated partial thromboplastin time; PC - protein C; aPC - activated protein C; DIC - disseminated intravascular coagulation; PRP - platelet rich blood plasma; PPP - platelet poor blood plasma; EI - ecamulin index; PI - prothrombin index; FIFPs - functionally inactive forms of prothrombin; NIH - National Institutes of Health units; ADP - adenosine diphosphate; BET - Brunauer, Emmett and Teller, the specific surface area of a sample is measured - including the pore size distribution; BJH - Barrett-Joyner-Halenda, parameter of the pore-size distribution; WMW - Wilcoxon-Mann-Whitney.
} 
(ES), $3^{\text {rd }}$ group - healthy rats + AC to determine effect of ES on healthy rats, $4^{\text {th }}$ group - healthy rats as intact control. 1st group \& 4th group of rats received only food (oat) and water and $2^{\text {nd }}$ group and $3^{\text {rd }}$ group of rats received $2 \mathrm{ml}$ of AC with food (oat) per each rat and water. $2^{\text {nd }}$ and $3^{\text {rd }}$ groups of rats began taking AC admixed with food 3 days before irradiation for preventive effect, on the day of irradiation and after irradiation (for radio-mitigation and treatment) until the end of the experiment. 20 animals were sacrificed under chloroform anesthesia on the $1^{\text {st }}$ day after irradiation, and the other 20 rats - on the $9^{\text {th }}$ day after irradiation.

Ionizing radiation was delivered using X-Rays from the RUM-17 calibrated irradiator (Dnipropetrovsk, URSS) with working current of $10.5 \mathrm{~mA}$, $0.5-\mathrm{mm} \mathrm{Cu}$ filter system; dose rate $-63 \mathrm{R}$ per min, time -11 min.

Animals were kept in standard cages with free access to food and water in accordance with the General Ethical Principles of Experiments on Animals (Ukraine, 2001), which are consistent with the provisions of "The European Convention for the Protection of Vertebrate Animals Used for Experimental and Other Scientific Purposes" (Strasbourg, 1986). This study was carried out with the approval of the Animal Care and Use Committee of the IEPOR of the NASU (Protocol No 4 from 16/04/2015).

Activated partial prothrombin time. Activated partial thromboplastin time (APTT) was measured according to the following procedure: $0.1 \mathrm{ml}$ of blood plasma was mixed with an equal volume of APTT-reagent and incubated for 3 minutes at $37^{\circ} \mathrm{C}$. Then the coagulation was initiated by adding $0.1 \mathrm{ml}$ of a $0.025 \mathrm{M}$ solution of $\mathrm{CaCl}_{2}$. Clotting time was monitored by the Coagulometer Solar CGL-2410 (Solar, Minsk, Belarus).

Fibrinogen concentration. Fibrinogen concentration in the blood plasma was determined by the modified spectrophotometric method. Blood plasma $(0.2 \mathrm{ml})$ and PBS $(1.7 \mathrm{ml})$ were mixed in glass tubes. Coagulation was initiated by the addition of $0.1 \mathrm{ml}$ of thrombin $(2 \mathrm{NIH} / \mathrm{ml})$. To avoid fibrin cross-linking $0.1 \mathrm{ml}$ of $40 \mathrm{mM}$ monoiodacetic acid was added to the sample. The mixture was incubated for $30 \mathrm{~min}$ at $37{ }^{\circ} \mathrm{C}$. The fibrin clot was removed and redissolved in $5 \mathrm{ml}$ of $1.5 \%$ acetic acid. The concentration of protein was measured using a spectrophotometer Optizen POP (Mecacys, Seongnam, South Korea) at $280 \mathrm{~nm}(\varepsilon=1.5)$.

Protein C level. PC level was determined using the activator of PC from Agkistrodon halys halys venom, as previously described [15]. The generation of activated PC was measured by chromogenic substrate assay using specific chromogenic substrate S2236 (p-Glu-Pro-Arg-pNa). The analysis was done in $0.05 \mathrm{M}$ Tris- $\mathrm{HCl}$ buffer $\mathrm{pH} 7.4$, at $37^{\circ} \mathrm{C}$. Chromogenic substrate concentration was $30 \mathrm{mM}$. The generation of para-nitroaniline was measured at $405 \mathrm{~nm}$ on a microtiter plate reader Multiscan EX (Thermo Fisher Scientific, Waltham, USA).

Platelet aggregation. Platelet aggregation measurements were based on changes in the turbidity of human PRP [16]. Aggregation was registered for 10 min using an Aggregometer Solar AP2110 (Minsk, Belarus). Platelet count was estimated using the same device. The initial rate and final level of aggregation were measured at $37{ }^{\circ} \mathrm{C}$ in the prepared mixture: $250 \mu$ of PRP incubated with $\mathrm{CaCl}_{2}$ $(10 \mu \mathrm{M})$ and activated by platelet agonist $\mathrm{ADP}$ $(12.5 \mu \mathrm{M})$ at $37^{\circ} \mathrm{C}$.

Functionally inactive forms of prothrombin (FIFPs). The level of functionally inactive forms of prothrombin (FIFPs) in blood was measured using thromboplastin as well as ecamulin activators of prothrombin. Ecamulin (prothrombin activator from Echis multisqumatis venom) is an enzyme that activates prothrombin, descarboxy-prothrombin and prethrombin 1 . It makes it possible to determine the total prothrombin level [17]. Thromboplastin acts through the tissue factor pathway of coagulation and activates only functionally active carboxylated and uncleaved forms of prothrombin as it is in the "prothrombin index" test. The difference in prothrombin level found by the ecamulin index (EI) and prothrombin index (PI) tests corresponds to the level of FIFPs.

Results of prothrombin and ecamulin tests were presented as the PI and EI as calculated by the formulas: $\mathrm{EI}=\mathrm{An} / \mathrm{Ap}$; PI $=\mathrm{An} / \mathrm{Ap}$, where An is the blood plasma thrombin activity of a healthy control animal; Ap is the blood plasma thrombin activity of exposed animal. The difference between PI and EI that was more than $10 \%$ indicated the accumulation of FIFPs above $12 \mu \mathrm{g} / \mathrm{ml}$, that was preliminarily assumed as evidence of thrombotic complications [18].

Thrombin generation was measured by chromogenic substrate assay [19] using thrombin-specific S2238 (H-D-Phe-Pip-Arg-pNA).

Statistics. Statistical data analysis was performed using the Wilcoxon-Mann-Whitney (WMW) test and Student's t-test. All blood coagulation assays were replicated thrice. Results are presented as 
means \pm standard deviation. Data were considered significant when $P<0.05$.

\section{Results and Discussion}

Coagulation system proteins. The APTT test is basic clotting test that indicates the ability of blood plasma to form a clot via the intrinsic pathway of the coagulation cascade. Despite the fact that the APTT was shown to be insufficient for accurate diagnostics [20], it can be used as a screening test to study biological models, with the obligatory application of more precise testing. Time of clotting in the APTT test was shortened on the 1st day after irradiation independently of ES to $24 \pm 4$ vs. $33 \pm 5$ s in control animals (Fig. 1). After 9 days after irradiation animals showed overall normalization of clotting time in the APTT test, two of eight self-recuperative rats animals after irradiation had slightly prolonged clotting time (Fig. 1).

Shortened APTT is a quite unusual condition [21], however it can be clearly associated with a hypercoagulability state [22] or can be caused by an increased level of fibrinogen [23]. Fibrinogen is the main protein of the coagulation system. Under the action of thrombin it converts to the monomeric fibrin that forms the core of a thrombus. On the other hand, fibrinogen is the protein of the acute phase of inflammation and an increase in its concentration is a known phenomenon of the inflammatory response [24].

We did not observe any significant irradiationstimulated changes in fibrinogen concentration. We can suggest that there is a tendency toward an increase in fibrinogen concentration in blood plasma of irradiated rats in both groups $(4.2 \pm 0.6 \mathrm{mg} / \mathrm{ml}$ vs. $3.2 \pm 0.3 \mathrm{mg} / \mathrm{ml}$ in control) that indicates the development of the inflammatory process. Administration of ES slightly prevented the increase in fibrinogen concentration after the irradiation $(3.8 \pm 0.6 \mathrm{mg} / \mathrm{ml})$. Changes in the fibrinogen level may be evidence of the inflammatory process, but this finding needs to be confirmed more precisely.

To confirm this finding, we studied the effect of irradiation and ES administration on the level of PC. PC is the major anticoagulant proenzyme of the coagulation system. Being activated by the

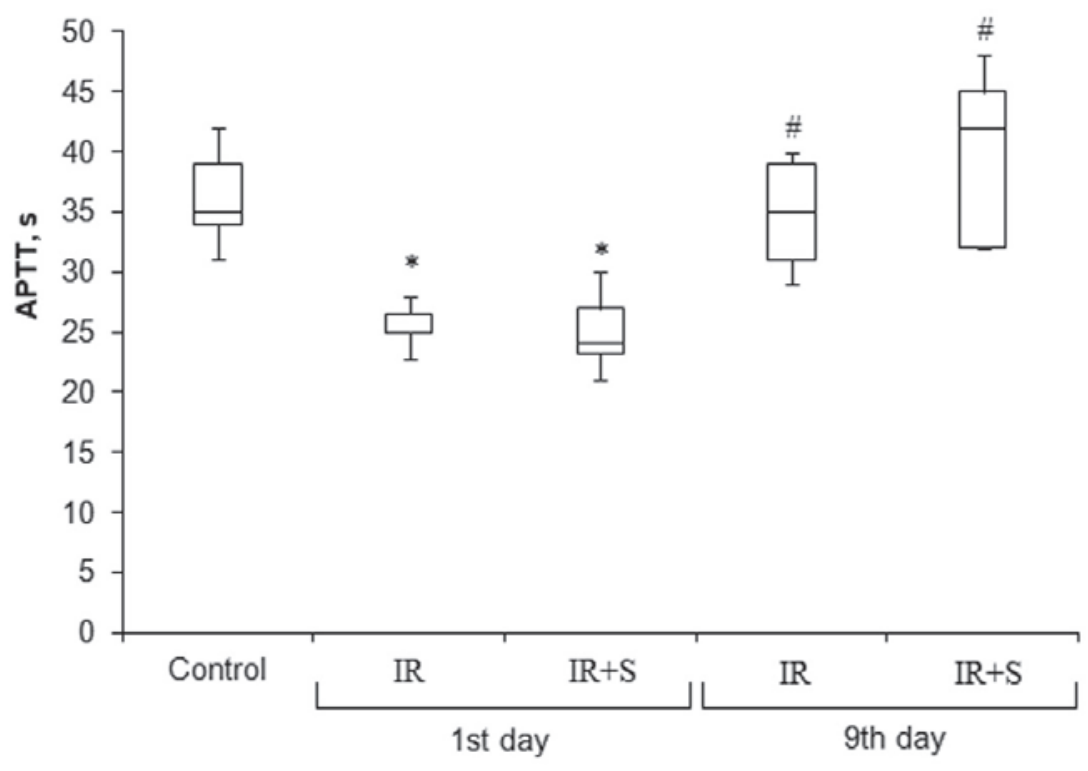

Fig. 1. Effect of irradiation at the dose of 6 Gy on clotting time in the activated partial thromboplastin time (APTT) test of rat blood plasma $(n=40)$. Control - clotting time of blood plasma of intact healthy animals including clotting time of blood plasma of healthy animals that received activated carbon (AC) admixed with food 3 days before irradiation and until the end of the experiment. IR - clotting time of blood plasma of irradiated rats on the $1^{\text {st }}$ and $9^{\text {th }}$ day after the irradiation. $I R+S$ - clotting time of blood plasma of irradiated rats on the $1^{\text {st }}$ and $9^{\text {th }}$ day after irradiation in rats that received $A C$ (denoted by " $S$ " for sorbent) admixed with food 3 days before irradiation for a preventive effect, on the day of irradiation and after irradiation until the end of the experiment. *According to Wilcoxon-Mann-Whitney (WMW) test the result is significant at $P<0.05$ (in comparison to control); ${ }^{*}$ According to $W M W$ test the result between columns is significant at $P<0.05$ (in comparison to data from $1^{\text {st }}$ day) 
thrombin-thrombomodulin complex, aPC (activated protein C) inactivates coagulation factors VIIIa and $\mathrm{Va}$, thereby reducing thrombin generation. On the other hand, aPC cleaves RAR-1 receptors of cells providing an anti-inflammatory and anti-apoptotic action. A decrease of the PC concentration is often a consequence of over-use of this enzyme caused by sporadic thrombin generation or the inflammation response [25].

The level of PC was decreased after irradiation (70 $\pm 10 \%)$ and partly restored on the 9th day after irradiation (87 $\pm 10 \%$ ) (Fig. 2). Administration of AC inhibited the drop in the PC concentration after irradiation (86 $\pm 15 \%)$ and accelerated its restoration on the $9^{\text {th }}$ day (103 $\pm 14 \%$ ) (Fig. 2). The drop in the concentration of PC in the blood plasma of irradiated rats demonstrates both the inflammatory response and low-grade generation of thrombin. Administration of ES allowed us to prevent such a dramatic decrease of PC and propagation of anti-inflammatory and anti-thrombotic effects.

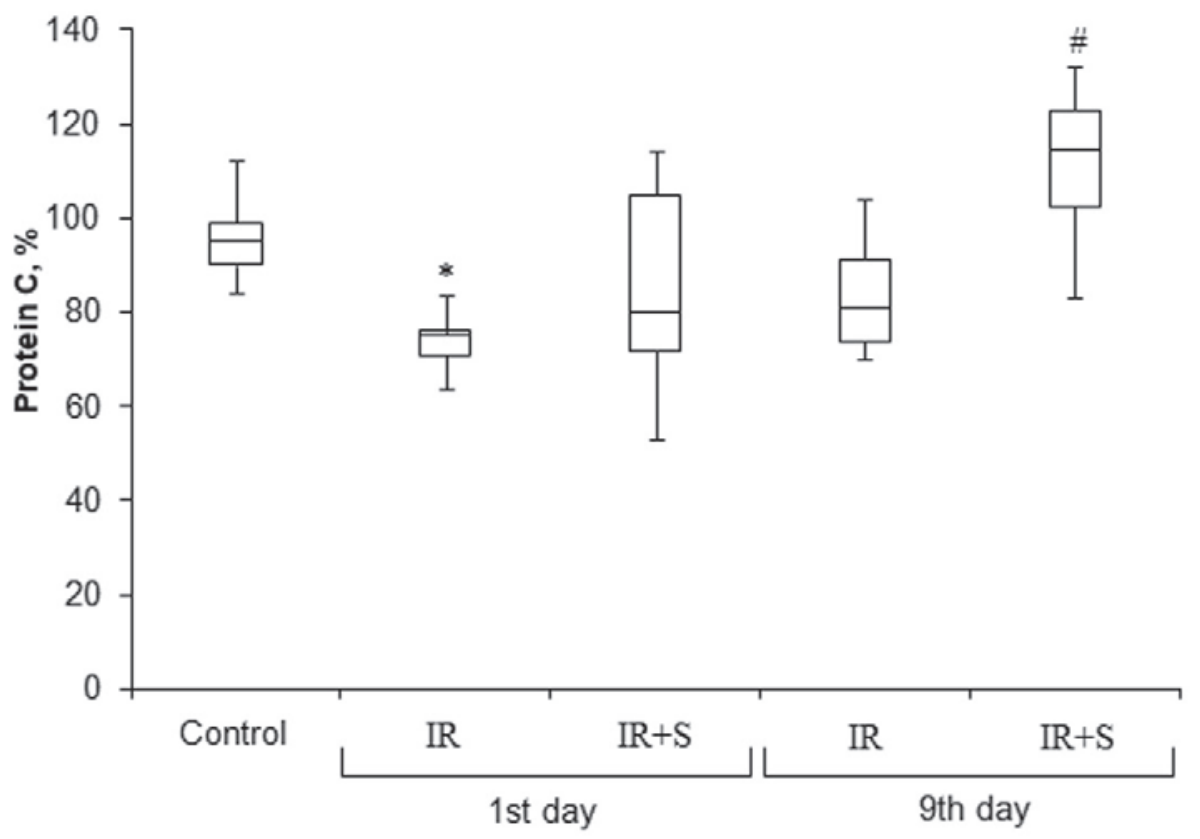

Fig. 2. Effect of irradiation at the dose of $6 \mathrm{~Gy}$ on the level of protein $C$ in the blood plasma of irradiated rats $(n=40)$. Control - the level of protein $C$ in healthy animals including this parameter of blood plasma in healthy animals that received activated carbon (AC) admixed with food 3 days before irradiation and until the end of the experiment. IR - The level of protein $C$ in the blood plasma of irradiated rats on the $1^{\text {st }}$ and $9^{\text {th }}$ day after the irradiation. $I R+S-$ The level of protein $C$ in the blood plasma of irradiated rats that received AC (denoted by " $S$ " for sorbent) admixed with food 3 days before irradiation, on the day of irradiation and after irradiation until the end of the experiment. *According to Wilcoxon-Mann-Whitney (WMW) test the result is significant at $P<0.05$ (in comparison to control); ${ }^{\# A c c o r d i n g ~ t o ~ W M W ~ t e s t ~ t h e ~ r e s u l t ~ b e t w e e n ~ c o l u m n s ~ i s ~}$ significant at $P<0.05$ (in comparison to data from $1^{\text {st }}$ day IR group) 

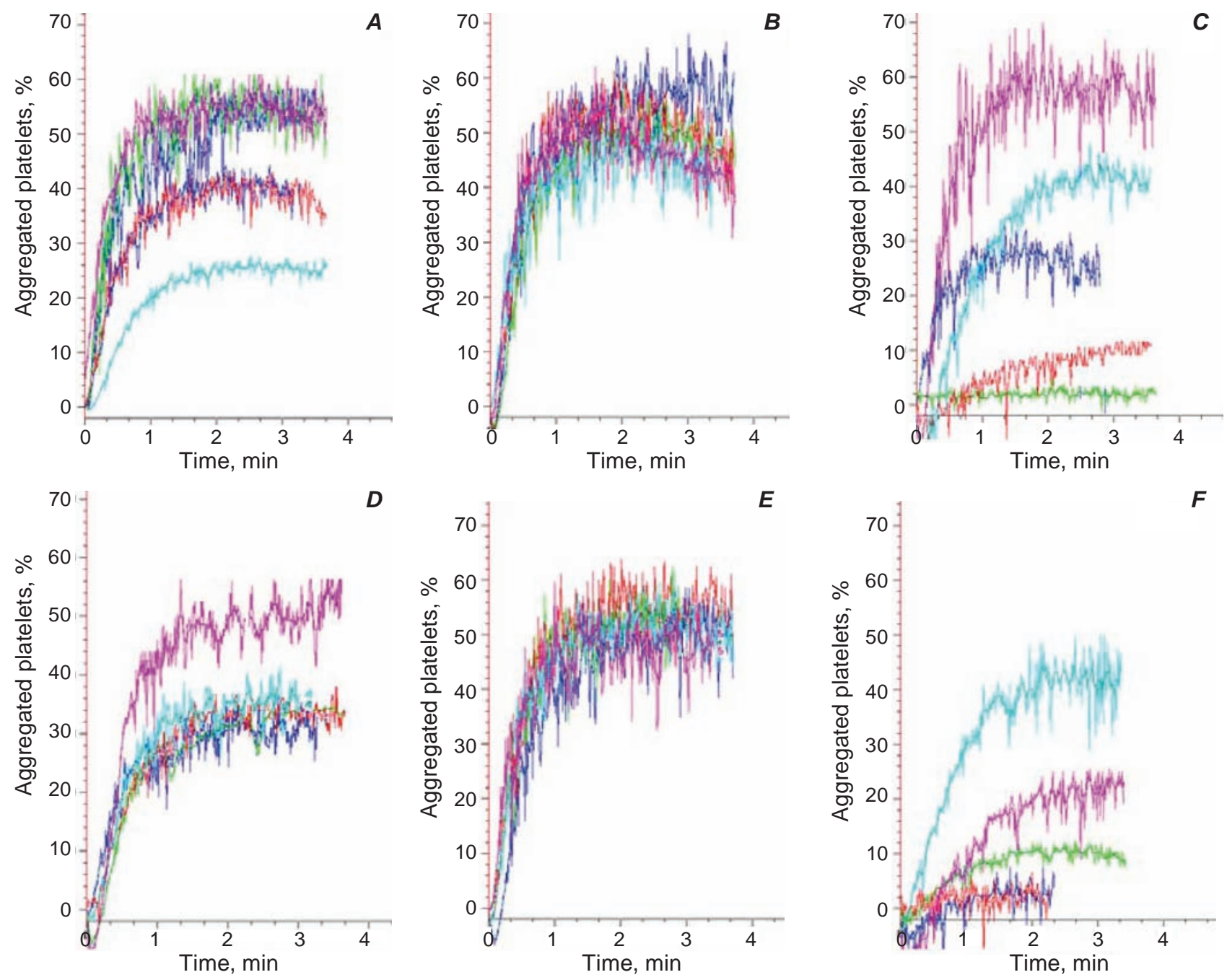

Fig. 3. Typical aggregation curves of platelets derived from the blood of intact healthy animals (A); irradiated rats on the $1^{\text {st }}(\boldsymbol{B})$ and $9^{\text {th }}(\boldsymbol{C})$ days after the irradiation; healthy animals that received activated carbon $(A C)$ (D); irradiated rats that received $A C$ on the $1^{\text {st }}(\boldsymbol{E})$ and $9^{\text {th }}(\boldsymbol{F})$ days after the irradiation. Each group contained 5 animals

pro-coagulant activity of blood after irradiation. Activated or disrupted endothelium can also activate platelets promoting their aggregation [31].

In addition to a slight increase in platelet count during the 1st day after the irradiation (Fig. 3), we detected the propagation of the platelet aggregation rate in both irradiated groups (Fig. 3, panels $B$ and $E$ ). The aggregation rate of control animals was not higher than $50 \%$ and unfortunately differed greatly between individual animals within a control group (mean was $43 \pm 10 \%$ ). However, all animals after irradiation had a platelet aggregation rate above 50\% (mean was $54 \pm 4 \%$ ). Panels $A-B, D-E$ in Fig. 3 clearly demonstrate this remarkable tendency.

On the $9^{\text {th }}$ day after irradiation we detected the visible result of thrombocytopenia (Fig. 3, panels $C$ and $F$ ). The rate of platelet aggregation in control groups was $40 \pm 11 \%$, most of the animals in both irradiated groups demonstrated greatly impaired platelet aggregation - mean rate was $24 \pm 20 \%$.

Thus platelet irradiation caused the increase of platelet reactivity on the $1^{\text {st }}$ day, increased the total pro-coagulant consequences, and resulted in thrombocytopenia in the later stages of ARS. Surprisingly, we did not observe any effects of administration of ES on the irradiation-induced number or rate of aggregation of platelets.

Functionally inactive forms of prothrombin. Observing the evidence of disseminated intravascular coagulation (changes of platelet reactivity and blood clotting time) and inflammatory process (higher fibrinogen concentrations, drop of PC level) 
we could not avoid the characterization of thrombin as the enzyme that is located at the crossroads between coagulation and inflammation [32, 33]. Thrombin is formed from the inactive precursor prothrombin as a result of a chain of hydrolytic reactions of the coagulation cascade [34].

Apart from its multiple functions thrombin can also act directly on prothrombin forming prethrombin [35]. The generation of this autolytical form is strongly correlated with the amount of active thrombin that appeared (Fig. 4). Previously its accumulation in blood plasma during pathologies was demonstrated [36].

Another functionally inactive form of prothrombin is uncarboxylated prothrombin that is formed in the case of liver disease that affects the process of carboxylation of prothrombin among other vitamin K-dependant proteins [37].

Previously we described the effective and useful method of prethrombin and uncarboxylated prothrombin detection in blood plasma. It consists in simultaneous application of the commonly used prothrombin test based on activation of the full-length molecule by exogenous thromboplastin and the ecamulin test based on application of prothrombin activator from the venom of Echis multisquamatis. Results are presented as the PI for prothrombin activation by thromboplastin, and as the EI for pro- thrombin activation by ecamulin. The difference between PI and EI indicates the accumulation of FIFPs.

Analysis on the $1^{\text {st }}$ day after irradiation showed the appearance of FIFPs in the blood plasma of selfrecuperative rats without ES (Fig. 5).

As far as the half-life of prothrombin in blood plasma being more than 48 hours [38], this finding cannot be explained by uncarboxylated prothrombin formation. The detected difference between PI and EI values on the $1^{\text {st }}$ day after irradiation indicates prethrombin generation and gives evidence of thrombin formation with subsequent low-grade inflammation and induction of coagulation. It was found that thrombin generation was greatly suppressed by enterosorption that acted by complete inhibition of prethrombin generation - no difference between PI and EI was observed in the group of irradiated rats that received ES (Fig. 5).

On the other hand, the detection of FIFPs on the $9^{\text {th }}$ day after irradiation is probably due also to the accumulation of decarboxy-prothrombin (Fig. 5). This effect can be observed during liver injury caused by inflammation or the action of toxic agents. As it was demonstrated, administration of ES diminished this harmful effect (Fig. 5).

Thus we detected the accumulation of FIFPs that indicated thrombin generation on the 1st day and liver disease on the 9th day after irradiation. Study

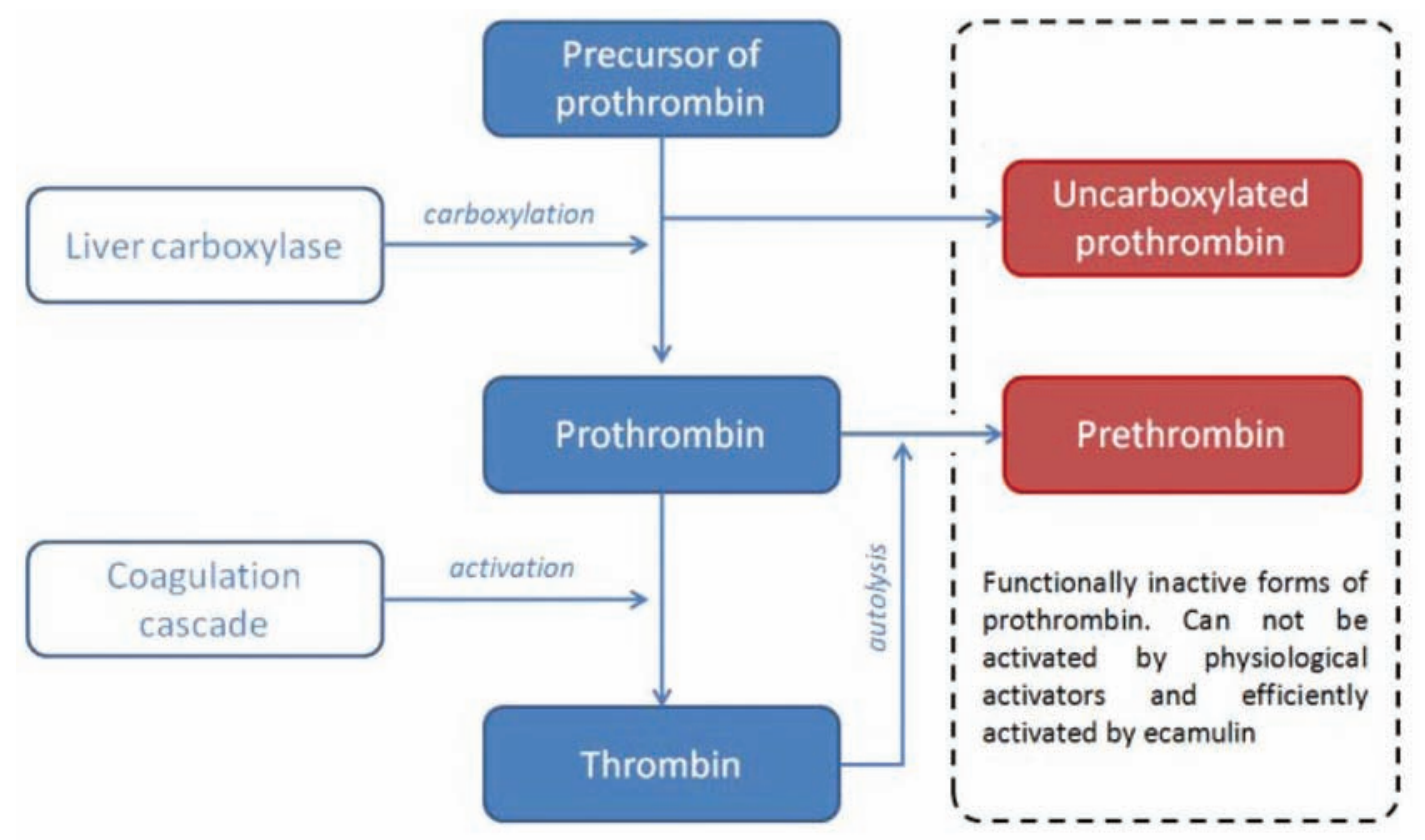

Fig. 4. Scheme of formation of functionally inactive forms of prothrombin (FIFPs): uncarboxylated prothrombin and prethrombin that cannot be activated by physiological activators in the coagulation cascade or under the action of thromboplastin, but can be efficiently activated by non-physiological activators (e.g. ecamulin) 


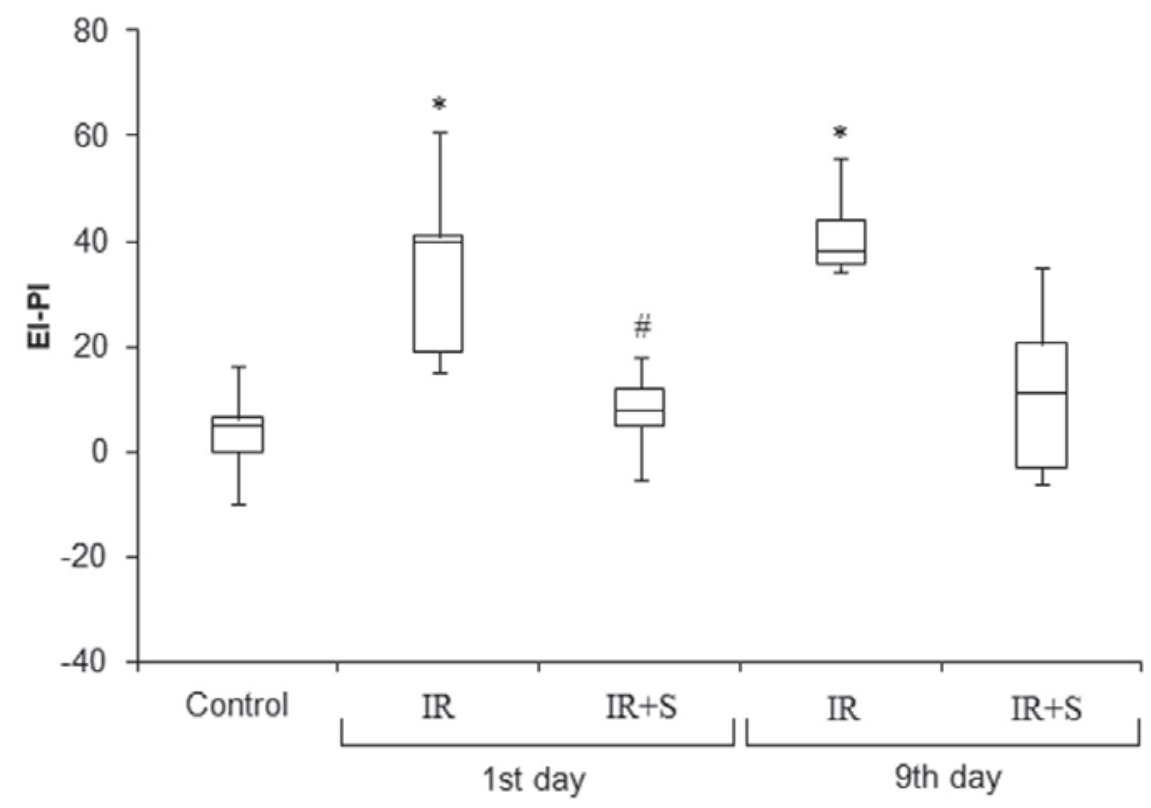

Fig. 5. Differences between the prothrombin index (PI) and ecamulin index (EI) for blood plasma of irradiated rats and irradiated rats that had received activated carbon $(A C)(n=40)$. PI and EI were calculated by the formulas: $E I=A p / A n ; P I=A p / A n$, where An is the blood plasma thrombin activity of a healthy control animal; Ap is the blood plasma thrombin activity of an exposed animal. Control - the PI-EI of healthy animals including this parameter of blood plasma in healthy animals that received activated carbon (AC) admixed with food 3 days before irradiation and until the end of the experiment. IR - The PI-EI in the blood plasma of irradiated rats on the $1^{\text {st }}$ and $9^{\text {th }}$ day after the irradiation. IR+S - The PI-EI in the blood plasma of irradiated rats that received $A C$ (denoted by " $S$ " for sorbent) admixed with food 3 days before irradiation, on the day of irradiation and after irradiation until the end of the experiment. *According to Wilcoxon-Mann-Whitney

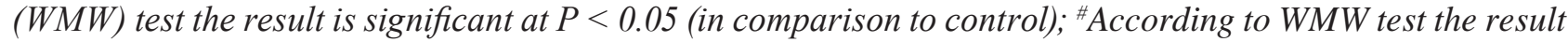
between columns is significant at $P<0.05$ (in comparison to data from $1^{\text {st }}$ and $9^{\text {th }}$ day IR group)

of the FIFPs allowed us to detect anti-inflammatory and hepatoprotective properties of the AC. Simultaneous application of the PI and EI was shown to be extremely sensitive for the detection of radiationinduced changes in the blood coagulation system.

Conclusions. Characterization of the hemostasis system of rats that were exposed to a semilethal dose of X-rays allowed us to select parameters that can be used for monitoring of ARS development. Apart from basic coagulation tests (APTT) and the measurement of platelet aggregation, fibrinogen and protein $C$ level we can recommend the determination of FIFPs as a useful tool for estimation of the hemostasis response after irradiation with $\mathrm{X}$-rays. This test indicates the intravascular thrombin generation and can help predict thrombotic complication or disseminated intravascular coagulation. Determination of FIFPs in blood plasma of irradiated rats allowed us to study the enterosorption effect on the develop- ment of irradiation-induced changes. It was shown that enterosorption with AC prevented accumulation of FIFPs which appears to be a newly discovered anti-thrombotic effect of therapy with AC.

Conflict of interest. Authors have completed the Unified Conflicts of Interest form at http:// ukrbiochemjournal.org/wp-content/uploads/2018/12/ coi_disclosure.pdf and declare no conflict of interest.

Acknowledgements. The publication contains the results of studies conducted by Horizon 2020 grant program MSCA-RISE No 734641. We thank Cedars-Sinai Medical Center's International Research and Innovation in Medicine Program, the Association for Regional Cooperation in the Fields of Health, Science and Technology (RECOOP HST Association) for their support of our organization as a participating Cedars - Sinai Medical Center RECOOP Research Centers (CRRC). 


\section{ПАРАМЕТРИ ЗСІДАННЯ ПЛАЗМИ КРОВІ ЩУ РІВ ІЗ ГОСТРОЮ ПРОМЕНЕВОЮ ХВОРОБОЮ ЗА УМОВ ЕНТЕРОСОРБЦЇ̈}

\author{
B. Чернишенко ${ }^{1 \bowtie}$, С. Снежкова ${ }^{2}$, \\ M. Мазур 2 , T. Чернишенко 1 , Т. Платонова ${ }^{1}$, \\ О. Сидоренко ${ }^{2}$, Е. Луговськой ${ }^{1}$ В. Ніколаєв ${ }^{2}$
}

\author{
${ }^{1}$ Інститут біохімії ім О. В. Палладіна \\ НАН України, Київ; \\ 凶e-mail: bio.cherv@gmail.com; \\ ${ }^{2}$ Інститут експериментальної \\ патології, онкології і радіобіології \\ ім. Р. Є. Кавецького НАН України, Київ
}

Радіаційно-індукована коагулопатія (РІК) $є$ однією з основних причин смерті під час гострої променевої хвороби (ГПХ). Метою цієї статті було охарактеризувати реакцію системи гемостазу на ГПХ помірного рівня на 1-шу і 9-ту добу після опромінення, виявити молекулярні маркери системи зсідання крові, які найбільше постраждализаГПХ,таоцінитиефектентеросорбції на розвиток індукованих опроміненням змін. Рівень агрегації тромбоцитів, активований частково тромбопластиновий час (АЧТЧ) i концентрацію фібриногену визначали стандартними методами. Рівень протеїну C (ПС) вимірювали за допомогою хромогенного субстрату S2366 (p-Glu-Pro-Arg-pNa) та ензимуактиватора 3 отрути Agkistrodon halys halys. Функціонально неактивні форми протромбіну (ФНФП) визначали, використовуючи паралельно два активатори - тромбопластин та активатор протромбіну з отрути Echis multisqumatis. Щури обох опромінених груп мали підвищений ризик внутрішньосудинного зсідання крові порівняно з обома контрольними групами. Виявлено статистично вірогідне скорочення часу зсідання крові в тесті АЧТЧ (24 \pm 4 с порівняно $333 \pm 5$ с) і підвищення концентрації фібриногену $(4,2 \pm 0,6$ мг/мл порівняно з 3,2 $\pm 0,3$ мг/мл). Обидва параметри нормалізувалися на 9-ту добу після радіаційного опромінення. Однак кількість тромбоцитів зменшувалася $\left(0,3 \cdot 10^{6} \pm 0,05 \cdot 10^{6} 1 /\right.$ мкл порівняно 3 0,145·10 $\pm 0,04 \cdot 10^{6} 1 /$ мкл) внаслідок порушення функції мегакаріоцитів. Рівень ПС знижувався після опромінення $(70 \pm 10 \%)$ і частково відновлювався на 9-ту добу $(87 \pm 10 \%)$. Введення щурам активованого вугілля (AB) запобігало зниженню концентрації ПС після опромінення

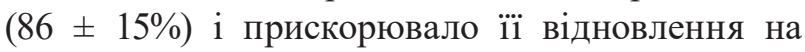
9 -ту добу $(103 \pm 14 \%)$. Статистично вірогідне накопичення ФНФП було виявлено в плазмі крові опромінених щурів (група 1) на обох досліджуваних етапах. ФНФП не були виявлені у жодного з опромінених щурів, які отримували $\mathrm{AB}$ (група 2). Характеристика системи гемостазу щурів, які піддавалися напівлетальній дозі опромінення, дозволила вибрати параметри, які можуть бути використані для моніторингу розвитку ГПХ. Крім основних коагуляційних тестів (АЧТЧ), вивчення агрегації тромбоцитів, рівня фібриногену та протеїну С, виявлення ФНФП може бути рекомендованим як дієвий інструмент для оцінки відповіді системи гемостазу на рентгенівське опромінення. Поява ФНФП свідчить про внутрішньосудинне утворення тромбіну i може вказувати на тромботичні ускладнення або дисеміноване внутрішньосудинне зсідання. Визначення ФНФП у плазмі крові опромінених щурів дозволило вивчити ефект ентеросорбції на розвиток змін, спричинених опроміненням. Показано, що ентеросорбція АВ перешкоджає накопиченню ФНФП. Антитромботичний ефект терапії $\mathrm{AB}$ виявлено вперше. Також встановлено, що ГПХ спричинює активацію системи гемостазу, утворення тромбіну (виявлене за рахунок утворення ФНФП), незначне запалення (на що вказує зниження концентрації ПС) і тромбоцитопенію. Ентеросорбція АВ мінімізує запальні та прокоагулянтні процеси, спричинені помірною дозою опромінення. Накопичення ФНФП можна вважати одним із найчутливіших маркерів відповіді системи зсідання крові на опромінення.

К л ю ч о в і с лов а: ентеросорбція, активоване вугілля, тромбоцити, зсідання крові, гострий променевий синдром помірного рівня.

\section{References}

1. Macià I Garau M, Lucas Calduch A, López EC. Radiobiology of the acute radiation syndrome. Rep Pract Oncol Radiother. 2011; 16(4): 123130.

2. Denham JW, Hauer-Jensen M, Peters LJ. Is it time for a new formalism to categorize normal tissue radiation injury? Int $J$ Radiat Oncol Biol Phys. 2001; 50(5): 1105-1106. 
3. Gourmelon P, Benderitter M, Bertho JM, Huet C, Gorin NC, De Revel P. European consensus on the medical management of acute radiation syndrome and analysis of the radiation accidents in Belgium and Senegal. Health Phys. 2010; 98(6): 825-832.

4. Krigsfeld GS, Savage AR, Billings PC, Lin L, Kennedy AR. Evidence for radiation-induced disseminated intravascular coagulation as a major cause of radiation-induced death in ferrets. Int J Radiat Oncol Biol Phys. 2014; 88(4): 940946.

5. Kennedy AR, Maity A, Sanzari JK. A review of radiation-induced coagulopathy and new findings to support potential prevention strategies and treatments. Radiat Res. 2016; 186(2): 121-140.

6. Levi M, Scully M. How I treat disseminated intravascular coagulation. Blood. 2018; 131(8): 845-854.

7. Levi M, van der Poll T. Inflammation and coagulation. Crit Care Med. 2010; 38(2 Suppl): S26-S34.

8. Esmon CT. The interactions between inflammation and coagulation. Br J Haematol. 2005; 131(4): 417-430.

9. Schaue D, Micewicz ED, Ratikan JA, Xie MW, Cheng G, McBride WH. Radiation and inflammation. Semin Radiat Oncol. 2015; 25(1): 4-10.

10. Hryschenko VA, Tomchuk VA, Lytvynenko OM, Chernyshenko VO, Gryschuk VI, Platonova TM. An estimate of protein synthesis in liver under induced hepatitis. Ukr Biokhim Zhurn. 2011; 83(1): 63-68. (In Ukrainian).

11. Dziuba OS, Chernyshenko VO, Hudz IeA, Kasatkina LO, Chernyshenko TM, Klymenko PP, Kosiakova HV, Platonova TM, Hula NM, Lugovskoy EV. Blood coagulation and aortic wall integrity in rats with obesityinduced insulin resistance. Ukr Biochem J. 2018; 90(2): 14-23.

12. Shevchuk OO, Snezhkova EA, Bardakhivskaya KI, Nikolaev VG. Adsorptive treatment of acute radiation sickness: past achievements and new prospects. Hemoperfusion, plasmaperfusion and other clinical uses of general, biospecific, immuno and leucocyte adsorbents. 2017; Chapter 8: 245-256.

13. Sarnatskaya VV, Sakhno L, Paziuk LM, Yushko LA, Rodionova NK, Maslenniy VN,
Sidorenko AS, Nikolaev V. Highly activated carbon enterosorbent mediates the suppression of paraneoplastic syndrome associated with Lewis lung carcinoma in mice. Exp Oncol. 2018; 40(1): 33-41.

14. Solovjov DA, Platonova TN, Ugarova TP. Purification and characterization of ecamulin a new prothrombin activator from the Echis multisquamatus snake venom. Biochemistry (Mosc). 1996; 61(6): 785-793.

15. Gornitskaia OV, Platonova TN. Isolation and properties of the protein C activator from Agkistrodon halys halys venom. Biomed Khim. 2003; 49(5): 470-478. (In Russian).

16. Cattaneo M, Cerletti C, Harrison P, Hayward CP, Kenny D, Nugent D, Nurden P, Rao AK, Schmaier AH, Watson SP, Lussana F, Pugliano MT, Michelson AD. Recommendations for the standardization of light transmission aggregometry: a consensus of the working party from the platelet physiology subcommittee of SSC/ISTH. J Thromb Haemost. 2013; 11(6): 1183-1189.

17. Korolova DS, Chernyshenko TM, Gornytska OV, Chernyshenko VO, Platonova TN. Meizothrombin preparation and its role in fibrin formation and platelet aggregation. Adv Biosci Biotechnol. 2014; 5(7): 588-595.

18. Korolova DS, Chernyshenko VO, Platonova TN, Chernyshenko TM, Lugovskoy EV. Detection of prethrombin 1 in human blood plasma. Int Blood Res Rev. 2016; 5(2): 1-7.

19. Gershkovich AA, Kibirev VK. Chromogenic and fluorogenic peptide substrates of proteolytic enzymes. Bioorg Khim. 1988; 14(11): 1461-1488. (In Russian).

20. Capoor MN, Stonemetz JL, Baird JC, Ahmed FS, Awan A, Birkenmaier C, Inchiosa MA Jr, Magid SK, McGoldrick K, Molmenti E, Naqvi S, Parker SD, Pothula SM, Shander A, Steen RG, Urban MK, Wall J, Fischetti VA. Prothrombin Time and Activated Partial Thromboplastin Time testing: a comparative effectiveness study in a million-patient sample. PLoS One. 2015; 10(8): e0133317.

21. Lippi G, Salvagno GL, Ippolito L, Franchini M, Favaloro EJ. Shortened activated partial thromboplastin time: causes and management. Blood Coagul Fibrinolysis. 2010; 21(5): 459-463.

22. Abdullah WZ. Shortened activated partial thromboplastin time (APTT): a simple but 
important marker of hypercoagulable state during acute coronary event. Coronary Artery Disease - New Insights and Novel Approaches. InTech, 2012. 157-166 pp.

23. Zhang X, Bai B. Correlation of fibrinogen level and absorbance change in both PT and APTT clotting curves on BCSXP. J Nanjing Med Univ. 2008; 22(3): 193-198.

24. Jain S, Gautam V, Naseem S. Acute-phase proteins: As diagnostic tool. J Pharm Bioallied Sci. 2011; 3(1): 118-127.

25. Bouwens EA, Stavenuiter F, Mosnier LO. Mechanisms of anticoagulant and cytoprotective actions of the protein C pathway. J Thromb Haemost. 2013; 11(Suppl 1): 242-253.

26. Dainiak N. Hematologic consequences of exposure to ionizing radiation. Exp Hematol. 2002; 30(6): 513-528.

27. Chen S, Su Y, Wang J. ROS-mediated platelet generation: a microenvironment-dependent manner for megakaryocyte proliferation, differentiation, and maturation. Cell Death Dis. 2013; 4(7): e722.

28. Wazny LD, Ariano RE. Evaluation and management of drug-induced thrombocytopenia in the acutely ill patient. Pharmacotherapy. 2000; 20(3): 292-307.

29. Venkatesulu BP, Mahadevan LS, Aliru ML, Yang X, Bodd MH, Singh PK, Yusuf SW, Abe JI, Krishnan S. Radiation-induced endothelial vascular injury: a review of possible mechanisms. JACC Basic Transl Sci. 2018; 3(4): 563-572.

30. van Hinsbergh VW. Endothelium - role in regulation of coagulation and inflammation. Semin Immunopathol. 2012; 34(1): 93-106.
31. Coenen DM, Mastenbroek TG, Cosemans JMEM. Platelet interaction with activated endothelium: mechanistic insights from microfluidics. Blood. 2017; 130(26): 2819-2828.

32. ten Cate $\mathrm{H}$. Tissue factor-driven thrombin generation and inflammation in atherosclerosis. Thromb Res. 2012; 129(Suppl 2): S38-S40.

33. Popović M, Smiljanić K, Dobutović B, Syrovets T, Simmet T, Isenović ER. Thrombin and vascular inflammation. Mol Cell Biochem. 2012; 359(1-2): 301-313.

34. Krishnaswamy S. The transition of prothrombin to thrombin. J Thromb Haemost. 2013; 11(Suppl 1): 265-276.

35. Chen Z, Pelc LA, Di Cera E. Crystal structure of prethrombin-1. Proc Natl Acad Sci USA. 2010; 107(45): 19278-19283.

36. McDuffie FC, Giffin C, Niedringhaus R, Mann KG, Owen CA Jr, Bowie EJ, Peterson J, Clark G, Hunder GG. Prothrombin, thrombin and prothrombin fragments in plasma of normal individuals and of patients with laboratory evidence of disseminated intravascular coagulation. Thromb Res. 1979; 16(5-6): 759773.

37. Suttie JW. Vitamin K in Health and Disease. Boca Raton: CRC Press, 2009. 231 p.

38. Bovill EG, Soll RF, Lynch M, Bhushan F, Landesman M, Freije M, Church W, McAuliffe T, Davidson K, Sadowski J. Vitamin K1 metabolism and the production of des-carboxy prothrombin and protein $\mathrm{C}$ in the term and premature neonate. Blood. 1993; 81(1): 77-83. 